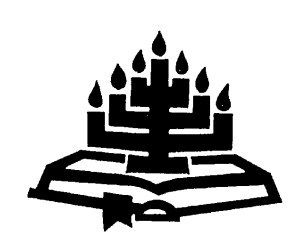

\title{
Is 'n kerkorde nie kragtens sy aard strydig met die werking van die Heilige Gees nie?
}

\author{
C.J. Smit \\ Skool vir Kerkwetenskappe (Navorsingsgenoot) \\ Potchefstroomkampus \\ Noordwes-Universiteit \\ POTCHEFSTROOM \\ E-pos: neelssmit@lantic.net
}

\begin{abstract}
Is a church order, according to it's nature, not contrary to the work of the Holy Spirit?
\end{abstract}

The question is whether a church order should be seen as antiSpiritual. Does a church order, in contrary to the work of the Holy Spirit, lead to rigidity of the church? By this question the controversy of the spiritual life of the church versus the institutional ordination of it has been raised as a real actuality in modern church life. The rejection of the institutional character of the church has a long history. To understand the true nature and the true Scriptural functioning of a church order one needs to get perspective on the new order which was given by Christ by means of his Holy Spirit. The new order must be seen as the way of life that was created by Christ on the profound ground of the expiation. In this context a church order must be understood as existing in the movement from the believer to the Word which occurs in the leading of the Spirit through ordained means. Seen in this sense, a church order must be regarded as a modus quo by which the church is governed by Christ by means of his Spirit, in order to maintain the new order which He created for his children. Seen as such, a church order is not a man created dispensable burden for the church of Christ, furthermore it is not an anti-Spiritual instrument by which the church is plunged into a dreary existence of cold formalism. To the contrary, a true Scriptural church order must be appreciated as a valuable instrument through which the governing labour of Christ, by means of his Holy Spirit, in the church should become visible. A Scriptural church order is in essence a correction on the separation of the Holy Spirit from the Word of God. Therefore a Scriptural church order should be considered as 
indispensable in this world for church being, according to the new order of life in Christ.

\section{Opsomming}

\section{Is 'n kerkorde nie kragtens sy aard strydig met die werkinge van die Heilige Gees nie?}

Die vraag is of 'n kerkorde as anti-geestelik gesien moet word. Lei 'n kerkorde, teen die werk van die Heilige Gees in, tot verstarring van die kerk? Deur hierdie vraag is die kontroversie tussen die geestelike lewe van die kerk en die institusionele ordening daarvan as 'n aktualiteit in die hedendaagse kerklike lewe aan die orde gestel. Die verwerping van die institusionele karakter van die kerk het 'n lang geskiedenis. Om die ware aard en die Skriftuurlike funksionering van 'n kerkorde te begryp, moet perspektief verkry word op die nuwe orde wat deur Christus gegee is deur sy Heilige Gees. Die nuwe orde moet gesien word as die lewenswyse wat deur Christus vir God se volk daargestel is op grond van die versoening. In hierdie konteks moet ' $n$ kerkorde geag word as die beweging van die gelowige na die Woord, wat deur die Gees plaasvind, by wyse van bepaalde middele. In hierdie sin kan die kerkorde selfs beskou word as 'n modus quo waardeur Christus die kerk by wyse van sy Gees regeer en waardeur Hy die nuwe orde onderhou wat Hy vir God se kinders daargestel het. So gesien, is die kerkorde nie 'n mensgemaakte las vir die kerk nie, verder is dit ook nie 'n anti-geestelike instrument waardeur die kerk in 'n bestaan van doodse formalisme gedompel word nie. Inteendeel, 'n Skrifgefundeerde kerkorde is ' $n$ waardevolle instrument waardeur die regering van Christus, deur die Heilige Gees, in die kerk sigbaar behoort te word. 'n Skrifgefundeerde kerkorde is in wese 'n korreksie op die skeiding tussen die Heilige Gees en die Woord van God. Daarom moet 'n Skrifgefundeerde kerkorde in ooreenstemming met die nuwe lewensorde in Christus as onontbeerlik vir kerkwees in hierdie wêreld geag word.

\section{Inleidend: vraagstelling}

'n Vaste orde waarvolgens die kerk ingerig en bestuur moet word, is in 'n tyd waarin postmoderne beskouings ook onder gelowiges al hoe meer geld, nie meer ' $n$ vanselfsprekendheid nie. Die vraag is of daar hoegenaamd 'n gestruktureerde orde vir die kerk as 'n geestelike gemeenskap in hierdie wêreld onder Christus se heerskappy nodig is? En hoe word so 'n orde toegepas? Hierdie vraag dring deur tot dié kernvrae: moet die kerk in sy besluitvorming dan nie eerder deur die Gees gelei word as deur eksakte ordereëlings wat deur die eeue geprosesseer is nie? Lei 'n kerkorde 
nie tot verstardheid, doodsheid in die kerk van die Here nie? 'n Kerk moet tog sy lewende liggaam op aarde wees. Is 'n kerkorde nie wesenlik anti-geestelik nie? Die vraag is dus of 'n kerkorde hoegenaamd bevorderlik vir die kerk se geestelike groei kan wees, en of dit nie strydig met die werking van die Heilige Gees is en tot koue formalisme en uiteindelik tot doodsheid in die kerk kan lei nie.

\section{Die geestelike lewe van die kerk versus die institusionele ordening daarvan}

Die vraagstelling raak die kontroversie in die geskiedenis van die teologie oor die verhouding tussen die geestelike lewe van die kerk en die institusionele ordening van die kerk (vgl. Ridderbos, 1971: 522).

Die verwerping van die institusionele sy van die kerk kom alreeds uit die doperse en libertynse strominge ná die Reformasie na vore. Calvyn het sterk standpunt ingeneem teen die doperse stroming wat die kerk wou vergeestelik, asof daar nie ook 'n sigbare, administratiewe uitdrukkingswyse vir die kerk noodsaaklik is nie (vgl. Balke, 1973:240 e.v). Dié gedagtegang dat die kerk slegs in 'n religieuse, of geestelike gestalte op aarde tot uitdrukking kom, is veral teen die einde van die negentiende eeu op 'n imposante wyse deur die juris, Rudolf Sohm, voorgedra.

Sohm (1892:1, 24 e.v.) se grondstelling was dat elke vorm van kerkreg radikaal met die wese van die kerk in stryd is: "Das Kirchenrecht steht in Widerspruch mit dem Wesen der Kirche. Die wahre Kirche, die Kirche Christi, kennt kein Kirchenrecht." (Sohm 1892:459.) Hy beskou die kerk as 'n volstrek geestelike realiteit wat as die onsigbare liggaam van Christus sy burgerreg in die hemel het, en wat geen uitwendige organisasie nodig het nie, maar deur gemeenskaplike geloof en geestelike charismata byeengehou word. Volgens Sohm $(1892: 102,103)$ het die menslike drang na uiterlike formele ordening en gepaardgaande regsverkeer menslike gesag in die kerk ten koste van God se gesag laat toeneem. Hy stel dat die kerk onmiddellike leiding van God deur die Gees ontvang, wat aan die bevoegde persone sy wil bekend maak en wat die kerk dienooreenkomstig lei. Van institusionele ordening of regsorde behoort, volgens Sohm, geen sprake in die kerk te wees nie.

Rutgers (1894:30 e.v.) stel teenoor Sohm dat die kerk nie op aarde kan bestaan as 'n bloot geestelike, mistieke sfeer nie. Kerkregering is noodsaaklik, juis daarin moet die Christusregering in die kerk sigbaar word. Harnack (1910:148 e.v.) sluit by Rutgers aan en 
bestry die ekstreme en onhoudbare spiritualisme in Sohm se kerkbeskouing, maar vind tog ook die institusionele en juridiese aspek van die kerklike organisasie vreemd aan die wese van die kerk. Vir Harnack raak kerkreg, kerkverband, amp, kortliks alles wat 'n institusionele karakter dra, nie die wese van die kerk nie. Dit is bloot van administratiewe betekenis en rus slegs op onderlinge kerklike afspraak. Hiervolgens kom Harnack tot die tweeslagtige gevolgtrekking dat die kerk wesenlik geestelik is, maar dat die organisasie van die institusionele sy van die kerk sekulêr gereël moet word (vgl. Ridderbos, 1971:490, 491).

Die beskouing dat die geestelike sy van die kerk in teëspraak met die organisatoriese sy daarvan is, loop uit op die wêreldwye spitsgedrewe apostolaatsteologie in die twintigste eeu, waarin ook die Neo-Pentekostalisme verteenwoordig word (vgl. Vorster, 1982:2). Hierdie apostolaatsteologie vorm op sy beurt weer die basis van ' $n$ postmoderne kerk buite die "mure" van die Skrifkerk, waarvan Hoekendijk (1964) alreeds in die begin van die tweede helfte van die vorige eeu geskryf het en wat in die "Nuwe Hervorming" in die begin van die 21e eeu 'n nuwe wending in Suid-Afrika verkry het (vgl. Muller, 2002:19 e.v.).

Aanvanklik het die verset teen die organisasie van die kerk daarop uitgeloop dat die kerk in hierdie kringe nog net verstaan is vanuit sy gerigtheid op die wêreld (Jonker, 1977:10), maar in die begin van die $21 \mathrm{e}$ eeu het dit, veral vanweë 'n radikaal gewysigde Skrifbeskouing, daartoe gelei dat die postmoderne kerk, byvoorbeeld spesifiek onder die eksponente van die "Nuwe Hervorming", veelal vanuit die spirituele belewenis van die individuele gelowige verstaan sou word (vgl. Kriel, 2002:156 e.v.).

Die anti-institusionele golf wat wêreldwyd in die kerk voorkom, vind reeds in Van den Berg (1969:11, 13, 69) 'n eksplisiete voorbeeld. Hy bepleit 'n totale verwerping van die institusionele sy van die kerk deur enige vorm van kerklike organisasie en kerkorde radikaal af te wys. Kerklike organisasie is vir hom 'n belemmering vir die kerk om waarlik kerk te wees, omdat die organisasie van die kerk "steriliserend" op die kerklike lewe sou inwerk. Hy is van mening dat die organisatoriese aspek van die kerk die gemeente van Christus "tot een gekerkerde kerk" inkluister.

Teenoor die afwysing van die organisatoriese of institusionele aspek van kerkwees, moet aan die ander kant ook gewaak word teen 'n institusionaliseringstendens wat eweneens die wesenlike gevaar van formalisme inhou. Dié tendens behels enersyds 'n burokratise- 
ringsproses wat in die kerk kan ontwikkel, waardeur die kerk oorgestruktureer word met kommissies, rade, funksionarisse, reglemente en allerlei bykomende organisatoriese aspekte wat niks met die wese van kerkwees te make het nie. Andersyds hou die institusionaliseringsproses in dat van die kerklike orde ' $n$ formalistiese reglement gemaak word waarin die doel, betekenis en gees van die kerkorde nie begryp word nie. Hiervolgens verstar die kerk in allerlei horisontaalgerigte reëlings en pligplegings waarin die geestelike diepgang van gelowiges deur uiterlike vormlikhede verhinder word (Spoelstra, 1973:3-5).

Binne die twee pole van die verwerping van kerklike organisasie enersyds (vergeesteliking van die kerk), en die oorstrukturering van die kerk andersyds (formalisering van die kerk), het die vraag na die werklike betekenis van die kerkorde gedurende die laaste helfte van die twintigste eeu na vore gekom. Hieroor het Hovius (1962:25) reeds gesê:

Het niet-geïnteresseerd-zijn in deze studie betekent een ernstige gevaar ... namelijk ... om Christus metterdaad te verloochenen terwijl men Hem met de mond blijft belijden. Het gaat bij de vraag van kerkorganisatie en kerkorde immers nie, zoals J.H. Gunning Jr. eens opmerkte, om een onwezenlijke vormkwestie maar om een geloofskwestie.

Ook 'n leidinggewende ekklesioloog in die tweede helfte van die twintigste eeu, W. van't Spijker (1974:38), skryf dat die vraag na kerklike orde uit 'n presbiteriaal-kerkregtelike hoek niks minder is nie as die vraag na die kerk se ontstaan, bestaan en voortbestaan in hierdie wêreld - dié vraag gaan wesenlik om die heerskappy van Jesus Christus in sy kerk.

\section{Die nuwe orde}

Die Skrif gaan nie uit van 'n eksak-geformuleerde kerkorde nie, maar vanuit 'n nuwe lewensorde as die verus ordo wat Christus deur sy verkondiging, sy dade en veral sy sterwe aan die kruis en sy opstanding uit die dood in hierdie wêreld gevestig het. Hierdie nuwe lewensorde rus op die versoening tussen mense en God, dit ontplooi in die koinonia tussen die gelowiges onderling en dit word gekonstrueer deur die charismata, soos laasgenoemde weer in die diakoniai tot uitdrukking kom - soos dit kortliks voorts uiteengesit word (Smit, 1984:22-37). 


\subsection{Versoening}

Die versoening as die oorsprong van die nuwe lewensorde vir God se mense, hou in dat Christus as die Versoener Hom met God se volk verenig, selfs geïdentifiseer het:

- Hy is die Hoof en die kerk, sy liggaam (Rom. 12; 1 Kor. 12)

- Hy is die Wynstok en sy kerk die lote (Joh. 15:1-10)

- Hy is die Hoeksteen en sy kerk die gebou (1 Pet. 2:1-10; Ef. 2:1922)

- Hy is die Herder en sy kerk die kudde (Joh. 10:16; vgl. Van der Walt, 1976:38, 55 e.v.)

Die versoening, as 'n daad van die hoogste liefde, moet vanuit Christus se identifisering en vereniging met God se volk verstaan word, as 'n gevolg van die vernietiging van die vyandskap met God en die herstel van die vrede met Hom (vgl. Ridderbos, 1971:198). Hyself is die Inisieerder van die radikaal nuwe verhouding met God (2 Kor. 5:15-21). Vir die ontplooiing van hierdie nuwe lewensorde laat God as' t ware sy mense teen wil en dank weer die plek inneem waarop hulle deur Hom "neergesit" is (Pop, 1978:337). Hierdie "nuwe plek" dui nie slegs die verhouding aan waarin God se mense teenoor Hom te staan kom nie, maar ook dié waarin hulle in hierdie nuwe lewensorde teenoor mekaar te staan kom (vgl. Ridderbos, 1971:200). Die nuwe orde, waarin die versoening met God deur mense belééf word, is uiteraard nie 'n lewenswyse waaraan wetties, deur formele voorskrifte, voldoen kan word nie. Bepalings wat in die Skrif vir die nuwe lewensorde gegee is, moet as die "bakens" van 'n innerlike lewenswet gesien word - 'n lewenswet van die hart. Dit gaan dus nie in die eerste plek om 'n nuwe struktuur met nuwe bepalings wat voorskriftelik afgedwing word nie, maar om 'n dinamiese lewenswyse waarin God deur sy Gees in liefde regeer. Die nuwe lewensorde is 'n polsende, vreugdevolle lewenswyse waarin God se nabyheid, in vrede met Hom, weerspieël word (Smit,1985:222). Hiervan sê Kamphuis (1966:14): "de hiërargie zegt: er is orde, dus móét er orde zijn; de Schrift leer: er is vrede, die verkondigt word, dus zij er alzo orde" (vgl. ook Kol. 1:20-22; Ef. 4:3). Dit is nie 'n orde wat soos die orde van 'n staatsbestel gedien moet word nie, maar omdat daar in Christus vrede met God gekom het, word Hy van harte, met blydskap, in dié nuwe orde gedien. Hier gaan dit slegs om sy eer (vgl. Ridderbos, 1971:199, 200; Rom. 5:1; 15:13): 
Nou leef die kerk uit de vrede Gods; daarom kan er 'orde' van vrede zijn in de gemeenschap der heiligen, die áls gemeenschap aan die vrede deel heeft in Christus Jezus ... ongetwijfeld heeft vrede hier vooral de betekenis van die 'ge-ordende toestand der dingen', maar dan toch niet naar de orde van een concentratie-kamp, maar duidelik in de zin van het oudtestamentische 'sjaloom': 'der heile, normale zustand' en wordt geschonken en gepredikt als voorwerp van goddelijke heilstoezegging. (Kamphuis, 1966:12, 13.)

Die verband wat deur 1 Korintiërs tussen vrede en orde gelê word, hou in dat waar God se vrede heers, as gevolg van die versoening, daar orde by wyse van harmonie in die organiese eenheid van die kerk en die Hoof tot uitdrukking kom. Omdat Hy die vrede van sy kerk is (Ef. 2:14 e.v.), kom die orde van die kerk van Hom (vgl. Van der Walt, 1976:160, 161). Vanuit die versoening is die harmonie tussen kerk en Hoof 'n uitdrukking van die nuwe orde wat deur die Hoof self gegee word en wat inhou dat die gemeenskap van mense met God en derhalwe met mekaar herstel is. Die gedrag van mense teenoor God en teenoor mekaar word nou deur liefde en geregtigheid gekenmerk (Van der Linde, 1977/1978:4; Snyman, 1977:53).

\subsection{Koinonia}

Koinonia dui op gemeensaamheid in die sin van "deelgenootskap", of "mede-deelgenootskap" in bepaalde omstandighede. In die Pauliniese betekenis van dié woord kom koinonia neer op deelgenootskap aan Christus en aan die Heilige Gees. So het Paulus dié woord aan 'n heidense omgewing ontleen en dit in die nuwe betekenisveld geplaas waarin die woord 'n benaming word vir die allerdiepste misterie in die lewe van die Christen, naamlik 'n uitdrukking van 'n nuwe lewensorde van deelgenootskap aan Christus en die Heilige Gees, waardeur die versoening met God die Vader uitgedruk word (vgl. Groenewald, 1932:153, 157). In die Pauliniese gebruik loop die uitsprake koinonía toû pneúmatos ("koinonia van die Gees") en koinonía toû úioû ("koinonia van die Seun") kwalitatief parallel. Dit lê in die wese van die Seun dat waar $\mathrm{Hy}$ is, is die Gees ook. Waar daar gemeenskap met Christus is, is daar ook gemeenskap met die Gees. Trouens, dit is die Heilige Gees wat die geloof deur die evangelie bewerk, waarvan Jesus Christus die inhoud is. Koinonia hou dus noodwendig in dat die gelowige in die nuwe lewensorde nie meer kata sarka ("deur die vlees") lewe nie, maar kata pneúma (“deur die Gees”) (Groenewald, 1932:177-179). 
Die deelgenootskap aan Christus en die Heilige Gees, soos dit deur die Woordverkondiging bewerk en deur die sakramentsgebruik versterk word, kom plaaslik tot uitdrukking in die gemeente as die liggaam van Christus en reik oor alle plaaslike, nasionale en internasionale grense waar gelowiges wêreldwyd in dieselfde deelgenootskap lewe. Dit beteken dat die koinonia van gelowiges, hoewel nie sinoniem met kerkverband nie, wêreldwyd kenmerkend is van ' $n$ nuwe lewensorde waarop die institutiewe sy van die kerk, sowel in plaaslike hoedanigheid as in ekumeniese verband, gebou word (vgl. Snyman, 1977:33, 34; Groenewald, 1932:157, 204; Du Plooy, 1982:241, 243). Die korporatiewe begrepenheid van gelowiges in die één liggaam van Christus, rus sowel op die versoening as op die koinonia. Vanweë die aard van hierdie "begrepenheid-in-die-Here" bepaal Hyself die aard en uitdrukkingswyse van die institusionele sy van hierdie nuwe orde.

Van vroeg af het teoloë in die gereformeerde tradisie bogemelde siening onderskryf. So het Calvyn die kerklike orde as 'n logiese uitvloeisel van die ooreenstemming van die Ordinatio Dei (wil van God) en die Spiritus Dei (Gees van God) geag, wat in die koinonia sy beslag vind (Milner, 1970:44). Trouens, sê Sillevis Smitt (1910: 57,62 ), die nuwe lewensorde van gelowiges is van die begin af in 'n vaste, blywende vorm deur die Heilige Gees gegee. Bakhuizen van den Brink (1968:20) toon aan dat dit dwarsdeur die Nuwe Testament duidelik is dat die Gees waaruit die vroeë Christene getrag het om te lewe, die Gees van die nuwe lewensorde is wat gesagvormend te werk gaan.

Op grond van versoening en koinonia vereis die nuwe lewensorde ook 'n institusionele orde, waarsonder daar nie 'n gemeenskapslewe in vrede met God op aarde in stand gehou kan word nie. Die lewe in Christus kan nooit ordeloos wees, of bloot op individualistiese menings gegrond wees nie, want "God is een God van orde. Zijn gansche schepping is ordelijk ingericht. Hy wil die orde ook in de kerken" (Kamphuis, 1966:11). God is 'n God van vrede en dáárom 'n God van orde (1 Kor. 14:33).

\subsection{Charismata en diakoniai}

Charismata moet afgelei word van die stamwoord charis wat "guns", "genade" beteken (Visser, 1978:23). Charismata beteken dan "genadegawes van God" teen die agtergrond van die versoening wat Christus bewerkstellig het. Diakoniai beteken "dienste" en dui spesifiek in die Nuwe-Testamentiese gebruik van die woord op die dienste (ampte) waarbinne die charismata tot ontplooiing kom (Floor, 
1979:91). Die charismata en die diakoniai moet dus nie as teenstellende aspekte gesien word nie, laasgenoemde is die "voertuig" waarbinne eersgenoemde "in beweging" kom. Die diakoniai is ' $n$ konkretisering en blywende realisering van die charismata. Tog moet hier meer presies gesê word: hoewel alle charismata nie diakoniai is nie, is alle diakoniai egter wel charismata (1 Tim. 4:16; 2 Tim. 1:6). Die diakoniai is die charismata wat amptelike erkenning in die institusionele beslag van die nuwe lewensorde ontvang (vgl. Floor, 1979:91). In die Skrif kan aangetoon word dat die diakoniai nie instellings is wat uit die gewone samelewingsverbande kom nie, maar dat dit in die Skrif verordineer is as spesifieke, eiesoortige funksies vir die kerk as die institusionalisering van die nuwe lewensorde wat in die Skrif bekendgemaak word (vgl. Van Itterzon, 1974:17). Sodoende kan die diakoniai beskou word as die "institusionele gawes" van die Heilige Gees waarin die charismata as die "geestelike gawes" van die Gees funksioneer (vgl. Ridderbos, 1971:498). Anders gesê, die charismata is aan bepaalde persone gegee wat hulle in staat stel om die kerk as die nuwe lewensorde van die Here op aarde deur die diakoniai op te bou en te vertroos (Rom. 1:11). Die charismata is die gawes wat deur die Heilige Gees gegee word en waardeur $\mathrm{Hy}$ die nuwe lewensorde as kerk, die liggaam van Christus op aarde, by wyse van die diakoniai opbou (vgl. Floor, 1979:86). Onder die charismata word derhalwe alles verstaan wat die Heilige Gees tot lering en vermaning, tot onderlinge diensbetoon en tot doeltreffende bestuur en regering van die kerk gee (Ridderbos, 1971:494). Hier moet egter steeds in ag geneem word dat alle charismata nie noodwendig as diakoniai in diens gestel word nie. Daar is die charismata in die gemeente wat deur die Heilige Gees in onderlinge liefdesbetoon gebruik word, sonder dat dit amptelike erkenning ontvang (Floor, 1979:92).

Waar Christus self die diakoniai vir sy kerk deur sy Gees verorden het, beteken dit nie dat Hy daarmee afstand gedoen het van sy regering in die kerk nie. Hy bly die Hoof van sy kerk, en Hy delegeer nie sy regeermag nie. Die diakoniai bedien slegs Christus se regering deur sy Woord en Gees. Deur die diakoniai volvoer Hyself die organisasie en die regering van sy kerk. Hyself is dus permanent as enigste Regeerder in sy kerk teenwoordig (vgl. Van't Spijker, 1972:12; Heyns, 1977:74). Die diakoniai tree dus nie magistraal op nie, maar ministerieel (1 Pet. 5:3). Die diakoniai se gesag kom slegs na vore in soverre Christus daardeur by wyse van die evangelie in die gemeente bedien word. Hier funksioneer dus nie 'n model van afgeleide gesag nie, maar wel van (be)dienende gesag (vgl. Küng, 
1978:389, 391, 392; Van der Linde, 1980:25; Van der Walt, 1976:60).

Die nuwe lewensorde, wat 'n orde van die hart is, word dus institusioneel gevestig as die liggaam van Christus deur die charismata wat van die Heilige Gees ontvang word. Floor $(1979: 95,96)$ onderskei ' $n$ viertal pastorale doelstellings waarin die charismata veral in die diakoniai tot uiting kom en waardeur die kerk deur die Heilige Gees opgebou word:

- Die opbou van die gemeente (1 Kor. 14:4, 26)

- Diens aan die gemeente (1 Kor. 12:25)

- Nuttigheid vir die gemeente se welsyn (1 Kor. 12:7; 14:6, 28)

- Ordereëlings in die gemeente (1 Kor. 14:26-40)

Waar die nuwe lewensorde in ' $n$ institusionele orde beveilig word, is dit nie om die uitlewing van die charismata in die gemeente te demp nie, maar om die beoefening daarvan te orden tot opbou van die gemeente. Waar die orde deur die uitlewing van die charismata versteur sou word, word die gemeente nie opgebou nie, maar afgebreek (Floor, 1979:96). Orde in die kerk beteken vir die individuele gelowige eerstens om met sy/haar charismata, uit liefde, die ander te dien en so gestalte te gee aan God se nuwe orde vir sy kinders (vgl. Grosheide, 1979:345).

\section{Die nuwe orde en kerkorde}

Die nuwe orde, wat die binnebrand van kerkwees vorm as die nuwe lewenswyse van die volk van God in Jesus Christus, is nie gelyk aan die kerkorde nie. Die kerkorde behoort egter vir die kerk die rigtingwyser na die Skrif te wees waarin die beginsels voldoende gegee word waarop hierdie nuwe lewensorde berus. Derhalwe behoort hierdie beginsels vir die kerk voldoende in die kerkorde weergegee te word (vgl. Sillevis Smitt, 1910:114; Bronkhorst, 1947:276; Nauta, 1971:16; Van Itterzon, 1974, 52; Pont, 1981:9; Smit, 1984:58-62). Soos die kerklike organisasie in die Nuwe Testament ontwikkel en ontplooi word, kom hierdie beginsels al hoe duideliker na vore. Daarom kan Polman (s.a.:32) in hierdie verband oor die pastorale briewe die gevolgtrekking maak: "Hier liggen de ordonnantiën voor de kerkelijke organisatie, die de Heilige Gees Zelf gegeven heeft." 
Ook Calvyn vind die absolute en onvervreembare fondament van die kerkorde as die geïnstitusionaliseerde ordereëling vir die kerk in die Ordinatio Dei, soos geopenbaar in die Skrif. Derhalwe mag die gelowiges se vryheid in hierdie nuwe lewensorde hulle nie deur gewetensdwang ontneem word as gevolg van bepalings wat nie op die Skrif steun nie (Calvyn, 1956: IV. X. 8, 10-15; vgl. Milner, 1970:75, 81 e.v.).

Die verhouding tussen die kerkorde en die Heilige Skrif moet as 'n noue band gesien word. Uit sy eksegese van 1 Timoteus 3:15 kom Smelik $(1973: 58,59)$ selfs tot die gevolgtrekking dat die kerkorde in die plek van die direkte apostoliese leiding in die kerk gekom het. Omdat die kerk sonder die persoonlike leiding van 'n apostoliese persoonlikheid moes bestaan, het die "kerkorde" waarvan hier sprake is, die doel om aan die gemeente 'n "stylvolle lewenswyse" en 'n vaste opbou ooreenkomstig die Skrif te gee: "Wonderlijk dat de eerste kerkordening in de vorm van een door bezorgdheid ingegeven improvisatie aan de Kerk geschonken wordt." (Smelik, 1973:59.)

'n Bepaalde orde as 'n nuwe lewenspatroon het vroeg in die eerste gemeente ontwikkel. Die patroon van dié orde het uitgekristalliseer rondom Woordbediening, doop, Nagmaal en tug (Sillevis Smitt, 1910:62). Die Skriftuurlike wyse van tug is byvoorbeeld ' $n$ duidelike uitkristallisering van 'n kerkorde waardeur die kerk in die nuwe lewensorde, wat as 'n vrug van die herskepping in en deur Christus gegee is, begrens word (vgl. Hand. 5:1-11).

'n Kerkorde het dus geen bestaansreg in 'n eie wetlikheid nie. Slegs die beginsels wat in die Skrif gegee is vir die nuwe lewensorde van die gelowiges, behoort deur "afleiding" en "nadere reëling" vir die geïnstitusionaliseerde lewe van die gelowiges toegepas te word na die eis van plek- en tydsomstandighede (Van der Linde, 1965:31; Van der Walt, 1976:161). Bouwman (1970:324,325) toon aan hoedat die kerkorde op Skrifbeginsels gegrond is, en tog ook ruimte laat vir die behoefte van plek- en tydsomstandighede:

(i) Dat die bedienaars, die ouderlinge en die diakens noodsaaklik vir die kerk is, is 'n Skrifgegewe (Ef. 4:11; 1 Tim. 5:17; Hand. 20:28; 6:2,3; ens.), maar hoeveel dienaars daar moet wees, word aan die kerke oorgelaat.

(ii) Dat die dienaars in die kerk verkies moet word, is 'n Skrifgegewe (Hand. 1:1-8; 6:1-6; 14:23; 20:28; Rom. 1:1; 10:15; 1 Kor. 1:1; Gal. 1:1; Ef. 1:1; Matt. 4:19; 9:37, 38; 
10:5, 7; 28:19; Joh. 21:15-17; ens.), maar op watter wyse die verkiesing moet plaasvind en vir hoe lank die ouderlinge en diakens moet dien, word aan die kerke oorgelaat.

(iii) Dat eenheid tussen kerke in kerkverband onderhou moet word kragtens die wese van die kerk, is 'n Skrifgegewe (Hand. 15; 2 Kor. 8; ens.), maar hoeveel kere meerdere vergaderings moet plaasvind, word aan die kerke oorgelaat.

Uit die voorafgaande word dié gevolgtrekking gemaak:

Die kerkorde behoort die nuwe lewensorde wat in die kerk geïnstitusionaliseer word, te dien en te beveilig deur die kerk in alle administratiewe en regulatiewe sake gedurig voor die Skrifbeginsels van sy bestaan te stel.

\section{Die kerkorde en die Heilige Gees}

Vanweë die kerkorde se binding aan die Skrif moet die kerkorde nie as 'n bundel reglemente los van die werking van die Heilige Gees gesien word nie. Trouens, die Skriftuurlik begronde kerkorde kan nie losgemaak word van die Heilige Gees nie:

The Church (order) must always be understood, therefore, as existing in the movement from the believer to the Word which occurs in the leading of the Spirit through ordained means. (Milner, 1970:192; vgl. ook Milner, 1970:4 e.v.)

Vir Calvyn is daar duidelik spesifieke kerkordelike aanwysings in die Skrif, asook die algemene reëls (generales regulas) wat die basis vir die kerkorde vorm (vgl. Plomp, 1967:15, 16) en waardeur die Heilige Gees in die ordening van die kerk meespreek. Daarom verklaar hy uitdruklik dat hy slegs die menslike insettinge goedkeur wat op God se gesag gegrond is en derhalwe uit die Skrif geneem is "en dus geheel en al Goddelijk zijn" (Calvyn, 1965: IV. X. 30). Ander teoloë erken ook dat alle Skriftuurlikbegronde kerkordelike bepalings as die werk van die Heilige Gees beskou moet word. Omdat die hele kerkorde op die Skrif gegrond moet word, moet dit geheel en al in ooreenstemming met die werking van die Heilige Gees gesien word (vgl. Van't Spijker, 1972:26, 27; Geiger, 1954:31). Ook Bucer, een van die reformatore, juis die reformator wat 'n duidelik naspeurbare invloed op Calvyn se denke uitgeoefen het (vgl. Van't Spijker, 1972:26, 27), betrek alle kerkordelike arbeid op die "Ordnung des Heiligen Geistes". 
Waar in die kerkregering omgegaan word met die kerkorde as die weergawe van die Skrifbepalings vir die kerk in sy voortbestaan, word die kerkregering onderhewig aan die Heilige Gees se werking gestel. Daarom sal in die samestelling en die toepassing van die kerkorde terdeë daarmee rekening gehou moet word dat dit die Woord is wat in die kerkregering aan die woord moet kom. Op hierdie wyse kan verhinder word dat aan die kerkorde 'n selfstandige funksie, los van die Woord, toegeken word (Smit, 1983:40).

\section{Slot}

Hoe word die institusionele orde van die kerk, soos in die kerkorde gereël, gerym met die vryheid van die Gees? Die fundamentele antwoord is dat dit die Gees is wat die nuwe lewensorde in die Skrif gee, waarin die "bakens" vir die institusionele bestaan van die kerk as beliggaming van die nuwe lewensorde omskryf word: "Het charisma tendeert dus naar het institusionele ..." en dit is 'n "vaste" instrument wat die Heilige Gees vir die gesonde funksionering van die gemeente gebruik (Ridderbos, 1971:497).

Die vraag na óf die vrye, geestelike lewe van die kerk, óf die kerkordelik-institusionele bestaan van die kerk, stel 'n ongeldige teenstelling. Die Heilige Gees lei die kerk in sy institusionele bestaan juis deur 'n Skrifbegronde kerkorde waarin die beginsels vir die institusionele lewe van God se volk in 'n nuwe lewensorde beliggaam word:

So gibt der Heilige Geist die Ordnungen in der Gemeinde, Ordnungen der Liebe um des Friedens willen; Geist und Ordnung, Geistkirche und Rechtskirche lassen sich nicht trennen. (Plathow, 1982:220.)

Noordmans (1980:390) maak die stelling dat dit die kerk se grondfout is om altyd in 'n meerdere of mindere mate oor die Gees te wil beskik. Dit is die kerk se erfsonde, waaruit al haar verdere gebreke en tekortkominge voortkom. "ledere kerkorde behoort eigenlijk niets anders te zijn, dan een correctie op deze grondfout." In dieselfde sin kan gesê word dat 'n Skrifgefundeerde kerkorde die korreksie is op kerklike strominge wat die Gees losmaak van die Woord. Waar die Gees losgemaak word van die Woord, heers emosiegedrewe willekeurigheid onder die waan van die leiding van die Heilige Gees. Hierdie willekeur kom gewoonlik tot uiting óf met negering van die Woord, óf in die plek van die Woord. 'n Beroep op 'n "waarheid" deur die persoonlike bekendmaking van die Gees, 
sonder toetsing daarvan aan die Woord, gee dan die deurslag vir 'n mensgedrewe kerkregering.

'n Skrifgefundeerde kerkorde is nie 'n waarborg daarteen nie, maar kan die "natuurlike" neiging van die kerk om oor die Gees te wil heers juis temper deur die kerk gedurig voor sy Skriftuurlike herkoms en bestemming te stel. Op hierdie wyse word 'n Skrifgefundeerde kerkorde juis 'n instrument waardeur die werking van die Gees in die kerk, ooreenkomstig bepalings van die Skrif, tot uitdrukking kom.

\section{Geraadpleegde bronne}

BAKHUIZEN VAN DEN BRINK, J.N. 1968. Ius Ecclesiasticum: historische beschouwingen over kerk en recht. Amsterdam: Noord-Hollandsche Uitgevers.

BALKE, W. 1973. Calvijn en de doperse radikalen. Amsterdam: Bolland.

BOUWMAN, H. 1970. Gereformeerde kerkrecht. Deel 1. Kampen: Kok.

BRONKHORST, A.J. 1947. Schrift en kerkorde: een bijdrage tot het onderzoek naar de mogelijkheid van een "Schriftuurlijke Kerkorde". Den Haag: ZuidHollandsche Boek en Handelsdrukkerij.

CALVYN, J. 1956. Institutie of onderwijzing in de Christelijke godsdienst. Uit Latyn vertaal deur A. Sizoo. Delft: Meinema.

DU PLOOY, A le R. 1982. Kerkverband: 'n gereformeerd-kerkregtelike studie. Pretoria: PU vir CHO. (Th.D-proefskrif.)

FLOOR, L. 1979. Hy wat met die Heilige Gees doop. Pretoria: NG Kerkboekhandel.

GEIGER, M. 1954. Wesen und Aufgabe kirchlicher Ordnung. Zürich: Evangelisher Verlag. (Theologische Studien, Heft 42. Herausgegeben von Karl Barth.)

GROENEWALD, E.P. 1932. Die ekklesia in die Nuwe Testament. Nederduitse gereformeerde teologiese tydskrif, 3(111):389-402.

GROSHEIDE, F.W. 1979. Commentary on the first epistle to the Corinthians. (In Stonehouse, B., ed. The new international commentary on the New Testament. Grand Rapids: Eerdmans.)

HARNACK, A. 1910. Entstehung und Entwickelung der Kirchenverfassung und des Kirchenrechts in den zwei ersten Jahrhunderten. Leipzig: Hinrich.

HEYNS, J.A. 1977. Die kerk. Pretoria: NG Kerkboekhandel.

HOEKENDIJK, J.C. 1964. De kerk binnenste buiten. Amsterdam: Ten Have.

HOVIUS, J. 1962. Het verband tussen onze belijdenis en onze kerkorde. Sneek: Weissenbach.

JONKER, W.D. 1977. Die unieke karakter van die kerk. In die Skriflig, 11(43):413.

KAMPHUIS, J. 1966. Verkenningen. Deel 3: Opstellen over kerk en kerkrecht. Goes: Oosterbaan \& Le Cointre.

KRIEL, J. \& KRIEL, C. 2002. Die evangelie(s): feit, fiksie of interpretasie? (In Muller, P., red. Die nuwe hervorming. Pretoria: Protea Boekhuis. p. 134160.)

KÜNG, H. 1978. The church. Trans. by R. \& R. Ockenden. London: Search. 
MILNER, B.C. 1970. Calvin's doctrine of the church. Leiden: Brill.

MULLER, P. 2002. Die postmoderne gelowige. (In Muller, P., red. Die nuwe hervorming. Pretoria: Protea Boekhuis. p. 19-37.)

NAUTA, D. 1971. Verklaring van de kerkorde van de Gereformeerde Kerken in Nederland. Kampen: Kok.

NOORDMANS, O. 1980. Verzamelde werken. Deel 8: Meditaties. Kampen: Kok.

PLATOW, M. 1982. Lehre und Ordnung im Leben der Kirche Heute: dogmatische, rechtsteologische und pastoral-theologische Überlegungen zu den Lebens- und Visitationsordnungen unserer evangelischen Kirche. Göttingen: Vandenhoek \& Ruprecht.

PLOMP, J. 1967. Beginselen van reformatorish kerkrecht. Kampen: Kok. (Kamper Cahiers, no. 4.)

POLMAN, A.D.R. s.a. Onze Nederlandsche Geloofsbelijdenis: verklaard uit het verleden geconfronteerd met de heden. Deel 3 \& 4. Franeker: Wever.

PONT, A.D. 1981. Die historiese agtergronde van ons kerklike reg. Pretoria: HAUM.

POP, F.J. 1978. De eerste brief van Paulus aan de Corinthiërs. 4e dr. Nijkerk: Callenbach.

RIDDERBOS, H. 1971. Paulus: ontwerp van zijn theologie. 2e dr. Kampen: Kok.

RUTGERS, F.L. 1894. Het kerkrecht: in zoover het de kerk met het recht in verband brengt. Amsterdam: Wormser.

SILLEVIS SMITT, P.A.E. 1910. De organisatie van de Christelijke kerk in den apostolischen tijd. Rotterdam: De Vries.

SMELIK, E.L. 1973. De brieven van Paulus aan Timotheüs, Titus en Filemon: de wegen der kerk. Nijkerk: Callenbach.

SMIT, C.J. 1983. Die kerkorde en die Heilige Skrif - 'n contradictio in terminis? In die Skriflig, 17(67):35-41.

SMIT, C.J. 1984. God se orde vir sy kerk - 'n beskouing oor kerkorde. Pretoria: NG Kerkboekhandel.

SMIT, C.J. 1985. Kerkreg en kerkorde in die lig van God se orde vir sy kerk. Potchefstroom: PU vir CHO. (Th.D.-proefskrif.)

SNYMAN, W.J. 1977. Nuwe en ou dinge: "uit die skat van die koninkryk". (In Snyman, P.C., red. Die kerk in die Nuwe Testament - en vandag. Potchefstroom: Pro Rege. p. 51-64.)

SOHM, R. 1892. Kirchenrecht. TI. 1. Leipzig: Duncker \& Humblot.

SPOELSTRA, B. 1973. Kerk as instituut ... en institusionalisering. In die Skriflig, 7(26):3-5.

VAN DEN BERG, M.R. 1969. De gekerkerde kerk. Amsterdam: Buijten \& Schipperheijn.

VAN DER LINDE, G.P.L. 1965. Die grondbeginsels van die presbiteriale kerkregeringstelsel. Potchefstroom: Pro Rege.

VAN DER LINDE, G.P.L. 1977/1978. Die kerkorde van die Gereformeerde Kerk in Suid-Afrika. Potchefstroom: PU vir CHO. (Ongepubliseerde klasdiktaat.)

VAN DER LINDE, G.P.L. 1980. Kerkreg. Deel 2. Potchefstroom: PU vir CHO. (Ongepubliseerde klasdiktaat.)

VAN DER WALT, J.J. 1976. Christus as Hoof van die kerk en die presbiteriale kerkregering. Potchefstroom: Pro Rege.

VAN ITTERZON, G.P. 1974. Het kerkelijk ambt in geding. Kampen: Kok.

VAN'T SPIJKER, W. 1972. Goddelijk recht en kerkelijke orde bij Martin Bucer. Kampen: Kok. (Apeldoornse studies, no. 3.) 
VAN'T SPIJKER, W. 1974. Democratisering van de kerk anno 1562. Kampen: Kok.

VISSER, L.L.J. 1978. De charismata. Pretoria: NG Kerkboekhandel.

VORSTER, J.M. 1982. Die hervorming en die gereformeerde kerke in 1982. Die Kerkblad, 85(2654):1-2.

\section{Kernbegrippe:}

geestelik

kerk

kerkorde

nuwe lewensorde

Key concepts:

church

church order

new order of life

spiritual 